\title{
US team returns with insights into Armenian earthquake
}

Washington

ACCORDING to a team of US seismologists and engineers that has just returned from the Soviet Union, the extraordinarily high death toll in the Armenian earthquake on 7 December was due in large part to poor assembly of prefabricated building parts, compounded by simple bad luck. Whereas most large earthquakes produce injuries and fatalities at a ratio of three or four to one, the numbers in this catastrophe were reversed.

Loring Wyllie, a structural engineer and co-leader of the 18-member team, said that although the town of Leninakan had suffered almost total devastation, older buildings and a few of the newer types had fared reasonably well. The most common apartment building style was a 9-storey frame construction, in which factorymade walls and floor are attached to a system of beams and columns. Out of 50 such buildings, fewer than 12 remained standing, and all were severely damaged. But about a dozen other buildings of a panel construction (in which the walls and floors are slotted together to form their own support), suffered much less damage.

Although analysis from the rubble was difficult, the engineers believed that the greatest fault with the frame buildings was that most of the stress is put on a fairly small number of connection points, and these connections were often poorly assembled. In the panel-construction buildings, by contrast, the load is spread more widely, and the joints can tolerate some movement before collapsing.

The faults of the frame building were magnified because the earthquake actually consisted of two strong shocks, with a tremor of Richter magnitude 5.8 coming 4 minutes after the initial 6.8 magnitude event. From the pattern of fatality in the wrecked buildings, the investigators concluded that the first shock had not demolished many of the apartment blocks, and that in the intervening 4 minutes residents had tried to escape, but had reached only the lower floors before the buildings collapsed on top of them. When the joints in the frame buildings failed, the floors collapsed vertically, leaving almost no spaces where people might have survived.

Fred Krimgold, of the College of Architecture and Urban Studies at Virginia Polytechnic Institute, said it was difficult to say whether the buildings were adequately designed, and might have done better had they been more carefully assembled. The basic designs came from Moscow, and had been modified for the local seismic conditions, but there seemed to be frequent discrepancies between the architectural drawings given to the team and the construction of the buildings themselves. According to Krimgold, the quality of the prefabricated parts seemed to be adequate, but there were many cases where parts had not fit together properly and joints had been improvised.

Seismologists with the US team, led by John Filson of the US Geological Survey, monitored the area for aftershocks and mapped out the fault region. A surface rupture of the Earth was found a few kilometres south of the epicentre, and about half way between the towns of Leninakan and Kirovakan. One of the puzzles confronting the seismologists was that damage in Kirovakan was relatively slight, although it is closer to the fault than Leninikan and has identical buildings. One small section of Kirovakan had been severely damaged, and local residents told the seismologists that the area was a drained marsh. This led Filson to suspect that local geological conditions created seismic resonances in some areas, amplifying the tremors. A similar phenomenon is thought to have occurred in the Mexico City earthquake of 1985 .

About 24,000 dead have now been found, but Krimgold suspects that a total fatality rate of around 60,000 is likely. Many had died of exposure in the days after the earthquake, and to add to the uncertainty there were rumours that as many as 100,000 refugees from the disturbances in Azerbaijan were in the area, of whom an unknown number might have perished.

Members of the team were impressed with the cooperation they were given by Soviet and Armenian officials, and by the candour of their discussions. Krimgold believes that the Soviets are anxious to learn from the disaster, and are already making moves to discard unsafe building designs and to revise building practices, perhaps by using fewer prefabricated parts and pouring more concrete on-site.

David Lindley

\section{Japan loses its most illustrious biologist}

Tokyo

JAPAN's Emperor, who died last Saturday, was a dedicated natural scientist who made several significant contributions to marine biology and botany. Emperor Hirohito's interest in marine biology began at an early age during visits to the imperial villa at Numazu on the coast of Suruga Bay south of Tokyo. In 1918, when still the teenaged crown prince, Hirohito discovered a new rare species of Pacific prawn, named Sympasiphaea imperialis after him, on the

\section{IMAGE UNAVAILABLE FOR COPYRIGHT REASONS}

\section{shore behind the villa.}

Ten years later, after ascending the throne, he established a personal research institute in the grounds of the palace in Tokyo. Barring official engagements, the emperor spent every Monday, Thursday and Saturday studying marine organisms, fungi and plants collected from the grounds of the palace and from various imperial villas dotted around the country.

Hirohito has numerous publications to his name, including a book on the hydrozoans of Sagami Bay, one of a series of volumes on the bay's fauna, which was published in August of last year shortly before he fell ill. His research has won him membership of the Royal Society of London and honorary memberships of the Linnean Society and the Zoological Society of London.

In 1975 he visited Woods Hole Oceanographic Institution, the Smithsonian Natural History Museum, and the Scripps Institution of Oceanography in the United States. It is said that he had to be persuaded to leave after spending an all-too-short hour with Scripps scientists Robert Hessler and William Newman examining hydrozoans.

The emperor has passed on his enthusiasm for biology to his children and grandchildren. The new Emperor Akihito is a keen marine biologist who studies goby fish. Akihito's brother Prince Hitachi is a cancer researcher, and the new emperor's second son Prince Aya, who is currently at the University of Oxford, is a specialist in the taxonomy of catfish. Biological research seems destined to continue at the palace.
David Swinbanks 